\title{
EDITORIAL
}

\section{IMUNODEFICIÊNCIA ASSOCIADA À MALÁRIA}

A imunidade antimalárica apresenta algumas peculiaridades. Somente depois de muitos anos, indivíduos de áreas endêmicas, submetidos a infecções freqüentes, desenvolvem sinais de proteção contra o plasmódio. Esta proteção não é total, no sentido de impedir o desenvolvimento do parasito, sendo somente capaz de manter a parasitemia sob controle e reduzir os sintomas de infecção ${ }^{14}$. Os raros individuos que referem total resistência ao plasmódio apresentam freqüentemente esplenomegalia, o que sugere a ocorrência de infecções subclínicas. Além disso, a imunidade depende para a sua manutenção de um continuado estímulo antigênico: individuos imunes, afastados da área endêmica por alguns anos, passam a apresentar suscetibilidade ao plasmódio comparável à de primoinfectados ${ }^{27}$.

Pode-se postular que estas características da imunidade antimalárica decorram da desregulação da resposta imune induzida pela infecção. A imunodepressão e a ativação policlonal de linfócitos com hiperglobulinemia e formação de auto-anticorpos que podem acompanhar a malária são consideradas como conseqüentes a alteração de mecanismos de imunorregulação ${ }^{31}$.

A imunodepressão associada à malária pode decorrer de diversos fatores. Embora os macrófagos de indivíduos infectados apresentem aumentos da capacidade fagocitária ${ }^{18} 20$ e sinais de ativação ${ }^{22} 28$, algumas disfunções já foram detectadas em modelos experimentais tais como deficiência no processamento ${ }^{9} \mathrm{e}$ apresentação de antígenos aos linfócitos ${ }^{29}$ e retardo na capacidade de mobilização e ativação durante a infecção $^{22}$. Sugeriu-se que parte desta disfunção pudesse ser devida a alterações na produção de mediadores pelos macrófagos. De fato, Wyler ${ }^{35}$ mostrou que células aderentes de baço de camundongos produzem quantidades subnormais de interleucina 1 (IL-1) essencial para a indução de resposta imune - a partir do 4. dia de infecçāo, quando também passavam a produzir substâncias supressoras da proliferação de linfócitos. Estes dados foram recentemente comprovados na malária humana. Linfócitos de individuos com infecção aguda, que apresentam deficiente proliferação quando estimulados com mitógenos ${ }^{12}$, recuperam totalmente a reatividade quando incubados com IL-1 recombinante ${ }^{23}$. Estas observações sugerem que a deficiência imunitária na malária pode ser secundária a um defeito na produção de IL-1 pelas células mononucleares e indicam que os receptores celulares

\section{IMMUNODEFICIENCY ASSOCIATED WITH MALARIA}

Malarial immunity presents certain peculiarities. It is only after many years that individuals in endemic areas subjected to frequent infections develop signs of protection against malaria. This protection is not total, in the sense of stopping development of the parasite, but it has the capacity to control the parasitaemia and reduce symptoms of infection ${ }^{14}$. Those rare individuals who claim total resistance to Plasmodium frequently have splenomegaly suggesting subclinical infections. In addition this immunity is dependent on continual antigenic stimulus for in subjects who leave the endemic area for several years, their susceptibility to Plasmodium reverts to that of a non immune ${ }^{27}$.

We can postulate that these characteristics of malarial immunity occur because of a regulation defect in the immune response induced by the infection. Immunodepression, polyclonal activation of lymphocytes with hyperglobulinaemia and the formation of autoantibodies which can accompany malaria are considered as consequences of alterations in the mechanism of immunoregulation ${ }^{31}$.

Immunodepression associated with malaria can occur as a result of diverse factors. Although the macrophages of infected individuals present an increase in phagocytic capacity 1820 and signs of activation $^{22} 28$, several defects have been detected in experimental models such as deficiencies in processing 9 and presenting antigens to lymphocytes ${ }^{29}$ and a delay in their mobilisation and activation during the infection $^{22}$. It has been suggested that part of this dysfunction could be due to alterations in the production of mediators by macrophages. In fact Wyler ${ }^{35}$ showed that adherent cells in the spleens of mice produce abnormal quantities of interleukin 1 (IL-1) - essential for the induction of the immune response - after the $4^{\text {th }}$ day of infection, when substances which supress the proliferation of lymphocytes are also produced. These findings were recently confirmed in human malaria. Lymphocytes of individuals with acute infections, which present diminished proliferation when stimulated with mitogens ${ }^{12}$, revert to normal activity when incubated with recombinant IL- ${ }^{23}$. These observations suggest that immune deficiency in malaria is secondary to a defect in the production of IL- 1 by mononuclear cells and indicate that the cellular receptors for IL-1 are preserved as well as the capacity to produce IL-2 by lymphocytes. Theander and cols ${ }^{19}$ showed that all of ten samples of lymphocytes from individuals 
para IL-1 estāo preservados, assim como a capacidade para produção de IL-2 pelos linfócitos. De fato, Theander e cols ${ }^{19}$ mostraram que a totalidade das dez amostras de linfócitos de individuos imunes a malária produzia IL-2 in vitro quando estimulados com antígenos de Candida albicans. Este dado poderia indicar que a população de linfócitos $T$ auxiliares - as principais células produtoras de IL-2 - manteriam sua função preservada durante a infecção aguda. Entretanto, demonstrou-se através da utilização de anticorpos monoclonais como marcadores, que na 1 1 semana da infecção por Plasmodium falciparum os linfócitos com fenótipo T4 - que incluem os T auxiliares - estão reduzidos em número. A partir da 2a semana, detectase um aumento dos linfócitos T8, que compreendem também os $\mathrm{T}$ supressores 25 .

Outro fator improtante na gênese da imunodepressão associada à malária é a linfopenia devida à diminuição de linfócitos $T$ e $B^{68}$ e que poderia ser, pelo menos em parte, causada pela ação de anticorpos linfocitotóxicos ${ }^{32}$. Em contraste com a redução do número de linfócitos circulantes, ocorre um aumento significativo de seu número nos órgãos linfóides, principalmente no baço. Menos de $24 \mathrm{~h}$ após a inoculação de plasmódio em camundongos detecta-se intensa proliferação de linfócitos esplênicos, tanto nas áreas de predominio de linfócitos $\mathrm{B}$ quanto nas de linfócitos $\mathrm{T}^{21}$. Tal proliferação poderia ser interpretada como devida a ativação policlonal de linfócitos, induzida por substâncias mitogênicas do parasito ${ }^{5}$. Entretanto, um outro fenômeno poderia também estar atuando: demonstrou-se recentemente que linfócitos de individuos com infecção aguda incubados com mitógeno apresentam maior resistência à ação inibitória da prostaglandina sobre a proliferação ${ }^{24}$. Este fenômeno, demonstrado tanto em relação à prostaglandina exógena quanto à endógena - que constitui uma substância imunomoduladora produzida por macrófagos - pode representar mais uma alteração dos mecanismos de imunorregulação na malária.

Uma das alterações importantes em relação às células mononucleares que ocorre na malária é $O$ aumento das células conhecidas como "nulas" ("null cells"), por não apresentarem alguns marcadores característicos de linfócitos $T$ e $B^{6}{ }^{34}$. Parte desta população tem sido identificada como células $\mathrm{NK}$, que possuem importantes funções imunorreguladoras ${ }^{7}$. Através da produção precoce e intensa de interferon alfa as células NK podem tanto ativar macrofagos como inibir a proliferação de linfócitos. Demonstrou-se que durante a fase aguda da malária humana ocorre aumento dos niveis de células NK circulantes, proporcional ao aumento de concentração de interferon alfa ${ }^{15}$, seguindo-se por queda durante a convalescèn$\mathrm{cia}^{2}$. As conseqüências destas alteraçōes sobre a re- immune to malaria produced IL-2 in vitro when stimulated with antigens of Candida albicans. This fact indicates that the population of $T$ helper cells - the principal cells producing IL-2 - are functioning well during acute infections. However, using monoclonal antibodies as markers of $\mathrm{T} 4$ lymphocytes, which include $T$ helper cells, the number of these cells is shown to be reduced in the first week of infection with Plasmodium falciparum. After the second week there is a rise in $\mathbf{T} 8$ lymphocytes which include the suppressor $T$ cells 25 .

Another factor important in the genesis of immunodepression associated with malaria is the lymphopenia due to the diminution of $T$ and $B$ lymphocytes, which could be partly due to lymphocytotoxic antibodies ${ }^{32}$. In contrast with the reduction in the number of circulating lymphocytes, there is an increase in these cells in lymphoid organs particularly the spleen. Less than 24 hours after inoculation of plasmodia in mice there is an intense proliferation of both $T$ and $B$ splenic lymphocytes ${ }^{21}$. This proliferation could be the result of polyclonal activation of lymphocytes induced by mitogenic substances of the parasite ${ }^{5}$. Another recently demonstrated possibility is that the lymphocytes of subjects with acute infection incubated with mitogen show marked resistence to the inhibitory effect of prostaglandins on the proliferation of these cells $^{24}$. This phenomenon, shown both in relation to exogenous and endogenous prostaglandins. which are immunomodulating substances produced by macrophages, may represent yet another alteration in the mechanisms of immunoregulation in malaria.

One of the important alterations in relation to mononuclear cells which occurs in malaria is an increase in what are known as null cells, since they to no: have the markers characteristic of $T$ and $B$ lymphocytes $^{634}$. A part of this population is identified as $\mathrm{NK}$ cells which have an important immunoregulatory function. Because of an early intense production of alpha interferon, NK cells can activate macrophages and inhibit the proliferation of lymphocytes. It has been. shown during the acute phase of human malaria that there is a rise in the level of circulating NK cells, proportional to the increase in the concentration of alpha interferon ${ }^{15}$ followed by a drop during convalescence ${ }^{2}$. The consequences of these alterations on the regulation of the immune response in malaria have still to be evaluated. Do these alterations in the mechanisms of immunoregulation in malaria have clinical effects and do they lead to a state of immunodeficiency? The observations available suggest that the reply is affirmative. Three lines of evidence can be considered, namely an increase in susceptibility to infection, an increase in tumour frequency and a deficient response to vaccination. It is known that malaria, specially in the acute 
gulação da resposta imune na malária ainda não foram avaliadas.

Teriam as alteraçōes dos mecanismos de imunorregulação na malária expressão clínica, ou seja, levariam a um estado de imunodeficiência? As observaçōes disponíveis indicam que a resposta é afirmativa. Três séries de evidências podem ser consideradas: aumento da suscetibilidade a infecções, aumento de freqüência de tumores e deficiente resposta a vacinações. Reconhece-se que a malária, especialmente na fase aguda, torna animais mais suscetiveis a certas infecções bacterianas ${ }^{3}$ e virais ${ }^{17}$. Não existem dados epidemiológicos decorrentes de estudos sistemáticos e controlados. Entretanto, foi recentemente observado que uma epidemia de sarampo em área endêmica de malária causou efeito devastador, com altas taxas de mortalidade entre a população infantil (MS Tada: comunicação pessoal, 1986). E interessante referir a alta prevalência de anticorpos anti-HTLVIII/LAV em pacientes de áreas endêmicas tanto da África ${ }^{1}$ como da América ${ }^{26}$, embora o significado desta associaçāo não tenha ainda sido esclarecido.

Experimentos em animais mostram que a malária pode aumentar a incidência de certos tumores induzidos por vírus, mas não daqueles provocados por substâncias químicas ${ }^{30}$. O efeito imunodepressor exercido pelo plasmódio pode ser mesmo mais potente do que o obtido com a administração de altas doses de ciclofosfamida ${ }^{30}$. A associação entre linfoma de Burkitt e malária vem sendo reconhecida há muitos anos. $O$ aparecimento do tumor em casos de malária não decorre de contatos mais freqüentes com o virus EB neste grupo, já que a prevalência de anticorpos antivírus EB é comparável em populações de áreas maláricas e não-maláricas ${ }^{13}$. Entretanto, indivíduos maláricos apresentam significativo comprometimento da imunidade dependente de linfócitos $T$ contra o vírus ${ }^{13}$. De fato, foi demonstrado que as alterações de linfócitos $\mathrm{T}$ que ocorrem durante a infecção por plasmódio permitem a proliferação descontrolada dos linfócitos $\mathrm{B}$ infectados por virus $\mathbf{E B}^{33}$.

A resposta inadequada a algumas vacinas pode ser considerada como decorrente da imunodeficiência associada à malária. Os dados disponíveis são, entretanto, limitados e contraditórios. Os trabalhos pioneiros de McGregor \& Barr ${ }^{10}$, demonstrando resposta deficiente à vacina antitetânica em crianças de área endêmica de malária não submetidas à quimioprofilaxia foram confirmados por um grupo 4 , mas não por outro $^{11}$. Utilizando-se vacina anti-Salmonella typhi, Greenwood e cols ${ }^{4}$ demonstraram deficiente formação de anticorpos contra antígeno $\mathrm{O}$ (timo-dependente) mas não antígeno $\mathbf{H}$ (timo-independente). Importante questão a ser levantada é se o estado de imunodeficiência de populações de áreas endèmicas poderia phase, can render animals more susceptible to certain bacterial ${ }^{3}$ and viral infections ${ }^{17}$. However there are no epidemiological data on systematic controlled studies. However, recently, an epidemic of measles was observed in an endemic area of malaria with devastating effects and a high mortality in the population (MS Tada: personal communication, 1986). Also of interest is the high prevalence of HLV III/LAV antibodies in patients in endemic areas of Africa ${ }^{1}$ and Ameri$\mathrm{ca}^{27}$, although the significance of this association is not clear.

Animal experiments show that malaria can increase the incidence of certain tumours induced by viruses, but not of those produced by chemical agents ${ }^{30}$ The immunodepressive effect of the plasmodial infection is more potent than that obtained by high doses of cyclophosphamide $^{30}$. An association between Burkitt lymphoma and malaria has been known for many years. The appearance of this tumour in cases of malaria is not associated with more frequent contact with the EB virus in this group, since the prevalence of anti-virus $\mathrm{EB}$ antibodies is comparable to that seen in populations in malarious and non malarious areas ${ }^{13}$. However, malarious individuals have a significant immune defect of their $T$ lymphocytes against the virus $^{13}$. In fact it has been shown that these alterations in $\mathrm{T}$ Iymphocytes which occur during the plasmodial infection permit an uncontrolled proliferation of $\mathbf{B}$ lymphocytes infected with the EB virus ${ }^{33}$.

The inadequate response to certain vaccines can be considered as the result of the immunodeficiency associated with malaria. However the data available is limited and contradictory. The initial paper of McGregor and Barr ${ }^{10}$ showed a deficient response to tetanus vaccine in children in a malarious area without chemoprophylaxis. This finding has been confirmed by one group ${ }^{4}$ but not by another ${ }^{11}$. Utilising a Salmonella typhi vaccine Greenwood and cols ${ }^{4}$ showed a deficient formation of antibodies against 0 antigen (thymus dependent) but not against antigen $H$, which is thymus independent. An important question which has been raised is if the state of immunodeficiency in populations in endemic areas could interfere with the immunogenic response to future antimalarial vaccines. This has been suggested by the work of Orjih and Nussenzweig ${ }^{16}$ who showed that in mice which had erythrocytic infections the immune response to sporozoite antigens was affected.

It can be concluded that infection with plasmodia produce profound and complex alterations in the mechanisms of immunoregulation in the host which are manifest as immunodeficiency, hyperglobulinaemia and the production of auto-antibodies. These alterations may explain the delay in development, the transitory nature and the deficiencies in acquired 
interferir com a resposta imunogênica de futuras vacinas antimaláricas, conforme sugerem os dados de Orjih \& Nussenzweig ${ }^{16}$ que demonstraram em camundongos que a infecção eritrocítica afeta a resposta imune a antígenos esporozoíticos.

Conclui-se que a infecção pelo plasmódio induz profundas e complexas alterações dos mecanismos de imunorregulação do hospedeiro que se manifestam por imunodeficiência, hiperglobulinemia e produção de auto-anticorpos. Tais alterações explicariam o retardo no desenvolvimento, a transitoriedade e a insuficiència da imunidade adquirida à malária. É possivel que a solução dos problemas atuais referentes à vacinação antimalárica passe necessariamente pelo esclarecimento das questões mais cruciais sobre o processo de imunorregulação na malária.

\section{REFERÊNCIAS BIBLIOGRÁFICAS}

1. Biggar R, Gigase PL, Melbye M, Kestens L, Sarin PS, Bodner AJ, Demets P, Stevens WJ, Paluku L, Delacollette C, Blattner WA. Elisa HTLV retrovirus antibody reactivity associated with malaria and immune complexes in healthy Africans. Lancet 2: 520-523, 1985.

2. Chaicumpa W, Atthasishtha $N$, Looareesuwan S, Tharavanij $\mathrm{S}$. Natural killer cells in peripheral blood of healthy individuals and patients with malaria. Southeast Asian Journal of Tropical Medicine and Public Health 13: 61-68, 1982.

3. Greenwood BM, Playfair JHL, Torrigiani G. Immunosuppression in murine malaria. I. General characteristics. Clinical and Experimental Immunology 8: 467-478, 1971.

4. Greenwood BM, Bradley-Moore AM, Palit A, Bryceson ADM. Immunosuppression in children with malaria. Lancet 1: 169-172, 1972.

5. Greenwood BM. Possible role of a B-cell mitogen in hyperglobulinemia in malaria and trypanosomiasis. Lancet 1: 435-436, 1974.

6. Greenwood BM, Oduloju AJ, Stratton D. Lymphocytes changes in acute malaria. Transactions of the Royal Society of Tropical Medicine and Hygiene 71: 408-410, 1977.

7. Herberman RB. Immunoregulation and natural killer cells. Molecular Immunology 19: 1313-1321, 1982.

8. Krettli A, Nussenzweig RS. Depletion of T and B lymphocytes during malaria infection. Cellular Immunology 13: 440-446, 1974.

9. Loose LD, Cook JA, Di Luzio NR. Malarial immunosuppression: a macrophage mediated defect.Proceedings of the Helminthological Society of Washington 39: 484491, 1972.

10. McGregor IA, Barr M. Antibody response to tetanus toxoid inoculation in malarious Gambian children. Transactions of the Royal Society of Tropical Medicine and Hygiene 56: 364-367, 1962.

11. Monjour L. Bourdillon F, Schlumberger M, Fayet MT, Michon C, Ballet JJ, Gouba E, Gentilini M. Étude de l'immunité humorale et cellulaire après vaccination anti- immunity to malaria. It is possible that solutions to current problems with antimalarial vaccines will depend on the clarification of crucial questions related to the process of immunoregulation in malaria.

tétanique chez l'enfant africain malnutri et paludeen. 1. Etude de la réponse en anticorps antitétaniques. Bulletin de l'Organisation Mondiale de la Sante 60: 589 $596,1982$.

12. Moore DL, Heyworth B, Brown J. PHA-induced lymphocyte transformation in leucocyte cultures from malarious, malnourished and control Gambian children. Clinical and Experimental Immunology 17: 647-658. 1974 .

13. Moss DJ, Burrows SR, Castelino DJ, Kane RG, Pope JH, Rickinson AB, Alpers MP, Heywood PF. A comparison of Epstein-Barr virus-specific T-cell immunity in malaria - endemic and non-endemic regions of Papua New Guinea. International Journal of Cancer 31: 727$732,1983$.

14. Newbold CI. Parasite antigens in protection. diagnosis and escape: Plasmodium. Current Topics in Microbiology and Immunology 120: 69-104, 1985

15. Ojo-Amazie EA, Salimonu LS, Williams AlO. Akinwolere OAO, Shabo R, Alm GV, Wigzell H. Positive correlation between degree of parasitemia, interferon titers and natural killer cell activity in Plasmodium falciparum - infected children. Journal of Immunology 127: 2296-2300, 1981.

16. Orjih AU, Nussenzweig RS. Plasmodium berghei: suppresion of antibody response to sporozoite stage by acute blood stage infection. Clinical and Experimental Immunology 38: 1-8, 1979.

17. Salaman MN, Wedderburn N, Bruce-Chwatt LJ. The immunodepressive effect of a murine plasmodium and its interaction with murine oncogenic viruses. Journal of General Microbiology 59: 383-391, 1969.

18. Shear HL, Nussenzweig RS, Bianco C. Immune phagocytosis in murine malaria. Joumal of Experimental Medicine 149: 1288-1298, 1979.

19. Theander TG, Bygbjerg IC, Jepsen S, Svenson M, Kharazmi A, Larsen PB, Bendtzen K. Proliferation induced by Plasmodium falciparum antigen and interleukin -2 production by lymphocytes isolated from malaria immune individuals. Infection and Immunity 53: 221$225,1986$.

20. Tosta CE, Wedderburn N. Immune phagocytosis of Plasmodium yoelii - infected erythrocytes by macrophages and eosinophils. Clinical and Experimental Immunology 42: 114-120, 1980.

21. Tosta $\mathrm{CE}$. The function of macrophages in rodent malaria. $\mathrm{PhD}$ thesis. Universidade de Londres, 1981

22. Tosta CE, Ruiz G, Wedderburn N. Effects of lethal and non-lethal malaria on the mononuclear phagocyte system. Revista da Sociedade Brasileira de Medicina Tropical 16: 58-67, 1983

23. Tosta CE, Santos LL, Ávila PC. Decreased mitogenic response of lymphocytes from malaria - infected individuals may not be due to deficiency in IL-1 receptors. 
In: Abstracts of the International Symposium on Immunomodulators: Biology and Therapeutic Applications 45, Rio de Janeiro, 1987.

24. Tosta CE, Santos LL, Ávila PC. Lymphocytes from malaria - infected individuals are resistant to the inhibitory effect of prostaglandin E2. In: Abstract of the International Symposium on Immunomodulators: Biology and Therapeutic Applications 46, Rio de Janeiro, 1987.

25. Troye-Blomberg M, Romero P, Patarroyo ME, Björkman A, Perlmann P. Regulation of the immune response in Plasmodium falciparum malaria. III Proliferative response to antigen in vitro and subset composition of $\mathrm{T}$ cells from patients with acute infection or from immune donors. Clinical and Experimental Immunology 58: 380387, 1984.

26. Volsky DJ, Wu YT, Stevenson M, Dewurst S, Sinangil F, Merino F, Rodriguez L, Godoy G. Antibodies to HTLV-III/LAV in Venezuela patients with acute malarial infections. New England Journal of Medicine 314: 647-648, 1986.

27. Walker E, Brodie C. Plasmodium falciparum in $\mathrm{Ni}$ gerians who live in Britain. British Medical Journal 248: 956, 1982.

28. Ward KN, Warrell MJ, Rhodes J, Looareesuwan S, White NJ. Altered expression of human monocyte Fc receptors in Plasmodium falciparum malaria. Infection and Immunity 44: 623-626, 1984.

29. Warren HS, Weidanz WP. Malarial immunodepression in vitro: adherent spleen cells are functionally defective as accessory cells in the response to mouse erythrocytes. European Journal ci' Immunology 6: 816-819, 1976.

30. Wedderburn N, Campa M, Tosta CE, Henderson DC. The effect of malaria on the growth of two syngeneic transplantable murine tumors. Annals of Tropical Medicine and Parasitology 75: 597-605, 1981.

31. Weidanz WP. Malaria and alterations in immune reactivity. British Medical Journal 38: 167-172, 1982.

32. Wells RA, Pavanand K, Zolyomi S, Permpanich B, MacDermott RP. Antilymphocytotoxic antibodies in sera of Thai adults infected with Plasmodium falciparum or Plasmodium vivax. Clinical and Experimental Immunology 39: 663-667, 1980.

33. Whittle HC, Brown J, Marsh K, Greenwood BM, Seidelin $\mathrm{P}$, Tighe $\mathrm{H}$, Wedderburn $\mathrm{L}$. T-cell control of Epstein-Barr virus - infected B cells is lost during $P$. falciparum malaria. Nature 312: 449-450, 1984.

34. Wyler DJ. Peripheral lymphocyte subpopulations in human $P$. falciparum malaria. Clinical and Experimental Immunology 23: 471-476, 1976.

35. Wyler DJ. Cellular aspects of immunoregulation in malaria. Bulletin of the World Health Organization 57 (Suppl. 1): 239-243, 1979.

\author{
Carlos Eduardo Tosta \\ Laboratório de Malária \\ Núcleo de Medicina Tropical e Nutrição \\ Universidade de Brasília \\ 70910 Brasilia, DF.
}

